\title{
PENGEMBANGAN PETUNJUK PRAKTIKUM IPA BERBASIS KULTUR MASYARAKAT PESISIR UNTUK SISWA KELAS VII SMPN 5 SUMENEP
}

\author{
Rasmiati $^{1}$, Lutfiana Fazat Azizah $^{2}$, Herowati $^{3}$ \\ Universitas Wiraraja ${ }^{1,2,3}$ \\ rasmirasmi779@gmail.com ${ }^{1}$
}

\begin{abstract}
ABSTRAK
Permasalahan yang dialami siswa kelas VII SMPN 5 Sumenep yaitu petunjuk praktikum IPA belum memuat komponennya secara jelas dan lengkap. Hal tersebut membuat siswa tidak memahami kegiatan praktikum yang dilakukan. Tujuan penelitian ini adalah untuk mengetahui kelayakan petunjuk praktikum IPA berbasis kultur masyarakat pesisir, serta respon siswa dan guru IPA terhadap petunjuk praktikum tersebut. Penelitian ini merupakan penelitian dan pengembangan (Research and Development) dengan menggunakan model pengembangan Sugiyono (2016). Subyek penelitian ini sebanyak 12 siswa kelas VII SMPN 5 Sumenep yang dipilih secara acak dengan 3 orang siswa pada uji simulasi produk dan 9 siswa pada uji coba pemakaian produk. Hasil kelayakan petunjuk praktikum IPA berbasis kultur masyarakat pesisir diperoleh rata-rata sebesar $74 \%$ dengan kriteria layak untuk isi produk dan 92,7\% untuk rata-rata tampilan produk dengan kriteria sangat layak. Adapun respon siswa diperoleh rata-rata sebesar 100\% untuk tahap simulasi produk dan 96,9\% pada uji coba pemakaian produk dengan kategori sangat baik. Respon guru terhadap petunjuk praktikum IPA berbasis kultur masyarakat pesisir termasuk dalam kategori sangat baik dengan rata-rata sebesar $100 \%$.
\end{abstract}

Kata kunci: Petunjuk Praktikum IPA, Berbasis Kultur Masyarakat Pesisir,

\section{ABSTRACT}

Problems experienced by students of class VII SMPN 5 Sumenep namely the science practicum instructionsdoes not contain the components clearly and completely. This makes students do not understand the activities practicum performed. The purpose of this research is to know the feasibility of science practicum instructionsbased on coastal community culture, and student and science teacher's response to the practicum instructions. This research is a research and development (Research and Development) by using Sugiyono development model (2018). The subjects of this study were 12 students of class VII SMPN 5 Sumenep selected at random with 3 students on product simulation test and 9 students on the trial of product usage. The results of feasibility of the science practicum instructionsbased on the culture of coastal communities were averaged at $74 \%$ with the criteria deserved for the content of the product and $92.7 \%$ for the average product display with very deserved criteria. The student's response is obtained on average $100 \%$ for product simulation phase and $96,9 \%$ on trial of product usage, with the same category that is very good. IPA teachers' responses to the science practicum instructions based on coastal societies culture are included in the excellent category with an average of $100 \%$.

Keyword: Science practicum instructions, Validation, Student response, Teacher response

\section{PENDAHULUAN}

Salah satu karakteristik kurikulum 2013 menyebutkan bahwa sekolah merupakan bagian dari masyarakat yang memberikan pengalaman belajar terencana dimana peserta didik menerapkan apa yang dipelajari di sekolah ke masyarakat dan memanfaatkan masyarakat sebagai sumber belajar (Permendikbud, 2013). Lebih lanjut UU RI No. 20 Tahun 2003 tentang Sistem 
Pendidikan Nasional Pasal 55 ayat (1) menyatakan bahwa "masyarakat berhak menyelenggarakan pendidikan berbasis masyarakat pada pendidikan formal dan nonformal sesuai dengan kekhasan agama, lingkungan sosial, dan budaya untuk kepentingan masyarakat, sehingga dalam hal ini guru dapat merancang pembelajaran dengan basis masyarakat di lingkungan yang dekat dengan siswa. Lebih spesifik lagi pada salah satu kompetensi inti mata pelajaran Ilmu Pengetahuan Alam (IPA) dalam kurikulum 2013 adalah memahami dan menerapkan pengetahuan (faktual, konseptual, dan prosedural) berdasarkan rasa ingin tahunya tentang ilmu pengetahuan, teknologi, seni, budaya terkait fenomena dan kejadian tampak mata, sehingga pembelajaran yang paling tepat diterapkan adalah pembelajaran melalui eksperimen (Subamia, Wahyuni and Widiasih, 2015).

Demi menunjang kegiatan praktikum maka diperlukan petunjuk praktikum untuk mempermudah siswa memahami kegiatan yang akan dilakukannya. Waluyo \& Parmin (2014) menyatakan bahwa "pentingnya panduan praktikum antara lain panduan praktikum bisa menjadi sumber belajar penunjang pembelajaran saat eksperimen, meningkatkan ketertarikan siswa dalam praktikum, siswa mengetahui cara kerja untuk melakukan praktikum dan mengetahui sistematika dalam pembuatan laporan praktikum".

Hasil wawancara pada tanggal 20 April 2017 kepada guru IPA kelas VII SMPN 5 Sumenep diperoleh data bahwa praktikum pernah dilaksanakan dua kali selama satu semester dan petunjuk praktikum menggunakan yang ada pada buku paket siswz. Data tersebut sesuai dengan hasil wawancara terhadap siswa pada empat kelas di kelas VII SMPN 5 Sumenep yang menyatakan bahwa praktikum IPA pernah dilaksanakan dua kali selama satu semester. Petunjuk praktikum yang mereka gunakan ada dalam buku paket siswa, tetapi mereka tidak mengerti terhadap petunjuk praktikum tersebut, kecuali guru menjelaskan terlebih dahulu apa yang akan mereka kerjakan. Hasil observasi terhadap buku paket siswa diketahui bahwa petunjuk praktikum yang dipakai siswa belum memuat komponen-komponennya dengan jelas dan lengkap.

Hal ini diperkuat dengan hasil angket yang disebarkan kepada siswa pada tanggal 22 April 2017. Hasil angket membuktikan hal yang sama terkait pelaksanaan praktikum hanya dua kali satu semester dan petunjuk praktik menggunakan buku paket. Data menunjukkan bahwa 49,5\% siswa tidak mengerti terhadap petunjuk praktikum yang mereka gunakan, tetapi siswa tetap suka jika guru mengadakan praktikum dan $70 \%$ siswa menyatakan mengerti materi pelajaran jika sudah dipraktikkan dari pada tidak dipraktikkan. Hal tersebut juga dapat terlihat dari hasil nilai kognitif siswa yaitu $31 \%$ siswa tidak tuntas pada materi yang dipraktikumkan. Oleh karena itu, adanya petunjuk praktikum yang lengkap, runtut dan jelas akan mempermudah siswa dalam melakukan praktikum.

Mengingat cara mengajar yang diterapkan oleh setiap sekolah, baik itu sekolah pada daerah pesisir, daerah perkotaan bahkan daerah pedalaman tidak dapat disamakan karena budaya mereka tidak sama, maka guru perlu memahami bahwa tidak semua praktikum yang dilaksanakan oleh satu sekolah dapat diterapkan pada sekolah lain dengan lingkungan yang berbeda. Petunjuk praktikum yang dibuat oleh guru seharusnya dikembangkan sesuai budaya siswa, sehingga siswa lebih mudah memahami kegiatan yang mereka lakukan karena materi yang disajikan berkenaan dengan lingkungan sekitar yang biasa mereka jumpai. Secara tidak langsung dengan kegiatan praktikum ini siswa lebih mengenal dan mencintai lingkungan sekitarnya.

Habibi, Anekawati and Wati (2012) menyatakan bahwa "Pembelajaran yang disajikan berdasarkan kultur dan kondisi 
lingkungan siswa sehari-hari akan lebih memberi pemahaman yang mendalam". Budaya (kultur) merupakan segala sesuatu yang diperoleh dari interaksi manusia dengan manusia lainnya dan juga dengan lingkungan sekitarnya. Hal tersebut menyimpulkan bahwa "Kultur masyarakat yang melingkupi kehidupan siswa tentunya berpengaruh terhadap bagaimana ia belajar, berperilaku dan beraktivitas (Habibi, Anekawati and Wati, 2012b). Sebagaimana hasil penelitian Subamia, Wahyuni and Widiasih (2015) mengemukakan bahwa perangkat penunjang praktikum IPA SMP berorientasi lingkungan dapat memfasilitasi siswa memperoleh keterampilan, memelihara sikap, dan mengembangkan pemahaman konsep-konsep yang berkaitan dengan pengalaman sehari-hari. Guru dan siswa juga memberi respon positif terhadap penerapan perangkat praktikum berorientasi lingkungan tersebut.

Alasan strategis pemanfaatan lingkungan sebagai sumber bahan praktikum adalah (1) upaya alternatif yang relatif lebih murah dan mudah didapat untuk melengkapi peralatan/ bahan yang dibutuhkan dalam pembelajaran, (2) dapat memberdayakan berbagai sumber daya yang ada di sekitar sekolah dan tempat tinggal peserta didik dan meningkatkan kreativitas dan inovasi guru beserta peserta didik, (3) upaya menyeragamkan sumber belajar peserta didik agar dapat membangun pengetahuan dan keterampilan serta sikap yang sesuai dengan kompetensi yang disarankan dalam kurikulum 2013. Di samping itu, juga akan memicu dan memacu upaya pelestarian lingkungan (Subamia, Wahyuni and Widiasih, 2015).

Oleh karena itu, penelitian ini dilakukan bertujuan untuk mengintegrasikan kultur masyarakat pesisir ke dalam petunjuk praktikum, sehingga dapat divalidasi oleh pakar dan dikatakan layak untuk digunakan dalam pembelajaran IPA. Petunjuk praktikum ini dikembangkan berbasis lingkungan siswa sendiri yaitu kultur masyarakat pesisir dan ketersediaan bahan disesuaikan dengan lingkungan siswa sehingga siswa akan mendapatkan pemahaman yang lebih bermakna dari pelaksanaan praktikum sebelumnya. Oleh karena itu, selain bertujuan untuk mengetahui kelayakan produk menurut para ahli, penelitian ini juga bertujuan untuk mengetahui respon siswa dan guru IPA terhadap petunjuk praktikum yang dikembangkan.

\section{METODE PENELITIAN}

Jenis penelitian ini merupakan penelitian dan pengembangan. Langkahlangkah penelitian menggunakan model yang dikembangkan oleh Sugiyono (2016) seperti pada Gambar 1.

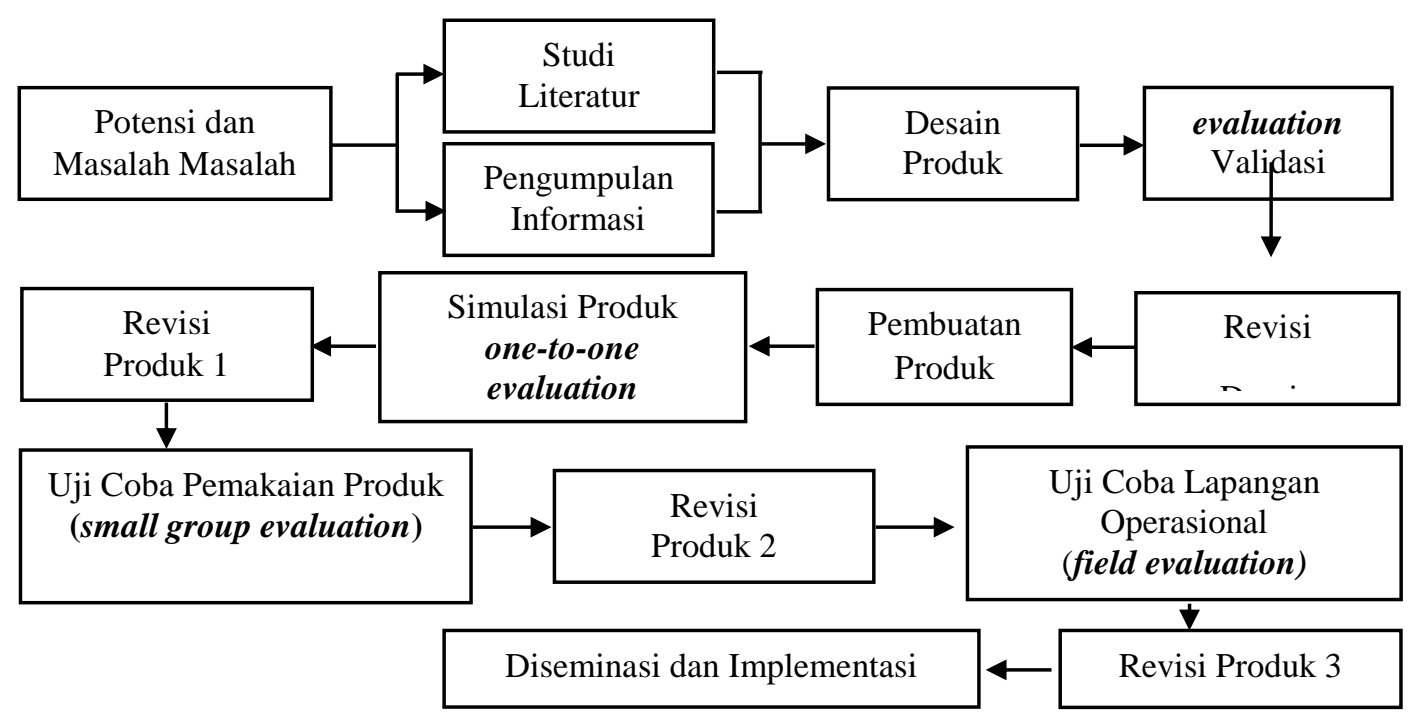

Gambar 1. Model Pengembangan Sugiyono 
Penelitian ini dihentikan pada tahap revisi produk 2 karena mempertimbangkan waktu penelitian yang tidak mencukupi untuk menyelesaikan semua tahap.

Populasi penelitian ini merupakan seluruh siswa kelas VII SMPN 5 Sumenep. Subjek penelitian dipilih 3 orang siswa pada tahap simulasi produk (one-to-one evaluation) dan 9 orang siswa pada tahap uji coba pemakaian produk (small group evaluation). Teknik menentukan sampel yaitu menggunakan random sampling.

Instrumen yang digunakan meliputi lembar validasi instrumen, petunjuk praktikum yang dikembangkan, dan angket respon yang diberikan kepada guru dan siswa. Lembar validasi instrumen merupakan lembar penilaian ahli terhadap instrumen yang akan digunakan dalam penelitian. Lembar validasi ini terdiri dari lembar validasi kelayakan isi dan tampilan petunjuk praktikum IPA berbasis kultur masyarakat pesisir, serta lembar validasi angket respon siswa dan guru terhadap petunjuk praktikum IPA berbasis kultur masyarakat pesisir. Validator yang digunakan sebagai penilai kelayakan isi dan tampilan petunjuk praktikum berbasis kultur masyarakat pesisir, sehingga menjadi acuan dan pedoman dalam merevisi produk terdiri dari 6 ahli (3 orang ahli media yang merupakan dosen Fakultas Keguruan dan Ilmu Pendidikan Universitas Wiraraja, dan 3 orang ahli desain yang berasal dari satuan pendidikan di luar Universitas Wiraraja.

Teknik analisis data penelitian ini menggunakan analisis persentase dan ratarata nilai yang didapatkan dari penilaian validator maupun respon siswa dan guru.

\section{a. Analisis Validasi Instrumen}

Data yang diperoleh dari hasil validasi instrumen dianalisis menggunakan rumus dan kriteria Tabel 1, dengan ketentuan bahwa instrumen dapat digunakan oleh validator untuk menilai produk jika mencapai nilai dengan kriteria baik. Skala yang digunakan yaitu skala Gutmann (ya dan tidak).
Kriteria (\%) $=\frac{A}{B} \times 100 \%$

Ket : $A=$ Jumlah skor jawaban Ya

$\mathrm{B}=$ Jumlah skor maksimum

Tabel 1. Kriteria Validasi Instrumen

\begin{tabular}{cc}
\hline Skor & Keterangan \\
\hline $81 \%-100 \%$ & Sangat baik \\
\hline $61 \%-80 \%$ & Baik \\
\hline $60 \%-41 \%$ & Cukup baik \\
\hline $40 \%-0 \%$ & Tidak baik \\
\hline
\end{tabular}

Sumber: Kunandar (2014)

\section{b. Analisis Validasi Produk}

Analisis data hasil validasi produk petunjuk praktikum yang didalamnya meliputi kelayakan isi dan kelayakan tampilan menggunakan rumus dan kriteria validasi petunjuk praktikum pada Tabel 2. Petunjuk praktikum dapat dikatakan valid jika mendapatkan nilai dengan kategori layak. Skala yang digunakan yaitu sangat baik (4), baik (3), kurang (2), dan sangat kurang (1).

$$
\text { Kriteria }(\%)=\frac{A}{B} \times 100 \%
$$

Ket : A = Jumlah nilai yang diperoleh

$\mathrm{B}=$ Skor maksimal

Tabel 2. Kriteria Validasi Desain Produk

\begin{tabular}{cc}
\hline $\begin{array}{c}\text { Persentase } \\
\text { Kelayakan }\end{array}$ & Kategori \\
\hline$<20 \%$ & Tidak Layak \\
\hline $21 \%-40 \%$ & Kurang Layak \\
\hline $41 \%-60 \%$ & Cukup Layak \\
\hline $61 \%-80 \%$ & Layak \\
\hline $81 \%-100 \%$ & Sangat Layak \\
\hline
\end{tabular}

Sumber: Setiawan and Wiyardi (2015)

\section{c. Analisis Respon}

Analisis data respon guru dan siswa terhadap produk dengan menggunakan rumus dan kriteria analisis respon siswa dan guru pada Tabel 3. Skala yang digunakan yaitu skala Gutmann (ya dan tidak).

$$
P=\frac{F}{N} \times 100 \%
$$

Ket: $\mathrm{P}=$ persentase

$$
\begin{aligned}
\mathrm{F}= & \text { banyaknya responden yang } \\
& \text { memiliki jawaban ya } \\
\mathrm{N}= & \text { banyaknya respoden yang } \\
& \text { menjawab kuesioner }
\end{aligned}
$$


Tabel 3. Kriteria Analisi Respon Siswa dan Guru

\begin{tabular}{ccc}
\hline Kategori & Persentase & Kriteria \\
\hline 1 & $81,26 \%-100 \%$ & Sangat Baik \\
\hline 2 & $62,51 \%-81,25 \%$ & Baik \\
\hline 3 & $43,76-62,50 \%$ & Cukup Baik \\
\hline 4 & $25-43,75 \%$ & Kurang Baik \\
\hline Sun
\end{tabular}

Sumber: Parmin (2013)

\section{HASIL PENELITIAN}

\section{Hasil Validasi Produk}

\section{a. Validasi Isi Produk}

Kelayakan isi petunjuk praktikum IPA berbasis kultur masyarakat pesisir meliputi 2 komponen yaitu kelayakan materi dan bahasa. Terdapat 9 indikator pernyataan yang dinilai yaitu 6 indikator pada komponen kelayakan materi dan 3 indikator pernyataan pada komponen kelayakan bahasa. Hasil yang didapatkan disajikan pada Tabel 4.
Tabel 4. Hasil Validasi Isi Produk

\begin{tabular}{|c|c|c|c|c|c|}
\hline No & Komponen & $\sum$ & $\begin{array}{l}\text { Rata- } \\
\text { Rata }\end{array}$ & $(\%)$ & Kriteria \\
\hline 1. & Materi & 175 & 29 & 73 & Layak \\
\hline 2. & Bahasa & 90 & 30 & 75 & Layak \\
\hline \multicolumn{3}{|c|}{ Jumlah } & \multicolumn{3}{|c|}{148} \\
\hline \multicolumn{3}{|c|}{ Rata-Rata } & & 74 & Layak \\
\hline
\end{tabular}

Sumber: Peneliti, diolah pada Juni 2017

Tabel 4 menunjukkan rata-rata hasil validasi isi produk pada materi dan bahasa yaitu 29 dan 30 dari nilai maksimal 40, sedangkan persentase komponen sebesar $73 \%$ untuk materi dan $75 \%$ untuk bahasa, dengan kriteria layak. Rata-rata kedua komponen yaitu $74 \%$ dengan kriteria layak. Jadi secara keseluruhan, isi petunjuk praktikum IPA yang dikembangkan sudah layak. Kelayakan isi untuk tiap indikator pernyataan baik pada komponen materi dan bahasa disajikan pada Gambar 2.

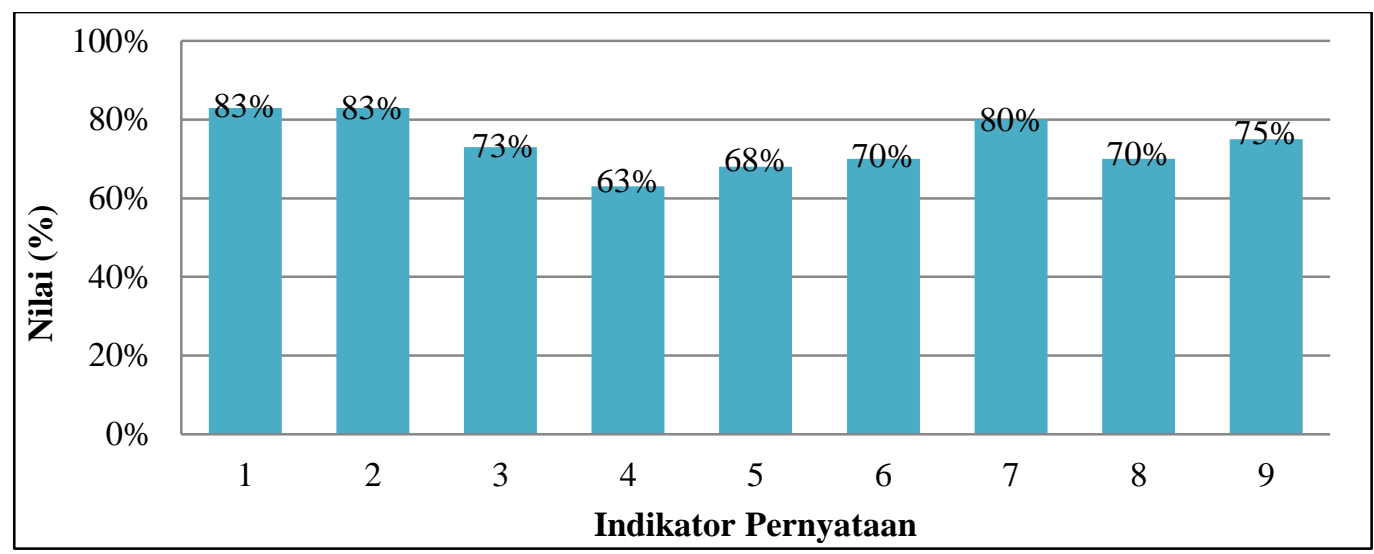

Gambar 2. Diagram Kelayakan Isi Produk Tiap Indikator Pernyataan

\section{Keterangan:}

$>\underline{\text { Materi }}$

1. Konsep IPA sesuai Kompetensi Inti dan Kompetensi Dasar.

2. Tujuan praktikum sesuai indikator pembelajaran.

3. Sesuai tahap perkembangan siswa dan memuat kultur masyarakat pesisir.

4. Gambar sesuai konsep dan kultur masyarakat pesisir

5. Contoh-contoh sesuai konsep dan kultur masyarakat pesisir.

6. Mempermudah kegiatan praktikum dan membantu siswa memahami konsep.

$>$ Bahasa

7. Bahasa yang digunakan komunikatif.

8. Kejelasan penggunaan kalimat.

9. Kesesuaian ejaan dengan Ejaan Bahasa Indonesia

Gambar 2 menunjukkan rata-rata hasil validasi oleh 3 orang validator terhadap isi petunjuk praktikum IPA bebasis kultur masyarakat pesisir pada tiap indikator penilaian. Persentase tertinggi terdapat pada indikator pernyataan No. 1 dan 2 yaitu kesesuaian konsep IPA dengan $\mathrm{KI}$ dan KD, serta tujuan praktikum sesuai dengan indikator pembelajaran dengan nilai yang sama yaitu sebesar $83 \%$. 
Persentase penilaian $61 \%-80 \%$ termasuk dalam kriteria layak, dan diatasnya yaitu $81 \%-100 \%$ termasuk kriteria sangat layak (Setiawan and Wiyardi, 2015), sehingga berdasarkan kriteria tersebut maka nomor 1 dan 2 mencapai kriteria sangat layak, dan untuk 6 indikator lainnya mencapai kriteria layak.

\section{b. Validasi Tampilan Produk}

Kelayakan tampilan petunjuk praktikum IPA berbasis kultur masyarakat pesisir divalidasi oleh 3 orang ahli yang menilai 8 indikator penilaian dalam lembar validasi. Hasil validasi dari masing-masing validator dapat dapat dilihat pada Tabel 5 .

Tabel 5. Hasil Validasi Tampilan Produk Oleh Tiap Validator

\begin{tabular}{cccccc}
\hline No. & Validator & Jumlah & Rata-Rata & Nilai (\%) & Kriteria \\
\hline 1. & Validator 1 & 27 & 3,4 & 84 & Sangat Layak \\
\hline 2. & Validator 2 & 31 & 3,9 & 97 & Sangat Layak \\
\hline 3. & Validator 3 & 31 & 3,9 & 97 & Sangat Layak \\
\hline \multicolumn{7}{c}{ Jumlah } & & $\mathbf{2 7 8}$ & S2,7 & Sangat Layak \\
\hline \multicolumn{7}{c}{ Rata-Rata }
\end{tabular}

Sumber: Peneliti, diolah pada Juni 2017

Berdasarkan Tabel 2 ketiga validator memberikan penilaian terhadap produk dengan kriteria penilaian yang sama yaitu sangat layak. Tetapi, persentase tertinggi diberikan oleh validator 2 dan 3 yaitu sebesar $97 \%$ dengan rata-rata 3,9 dari rata-rata skor maksimal yaitu 4 . Rata-rata penilaian yang diberikan oleh ketiga validator tersebut yaitu sebesar $92,7 \%$ dengan kriteria sangat layak. Sedangkan kelayakan untuk masing-masing indikator penilaian dapat dilihat pada Gambar 3.

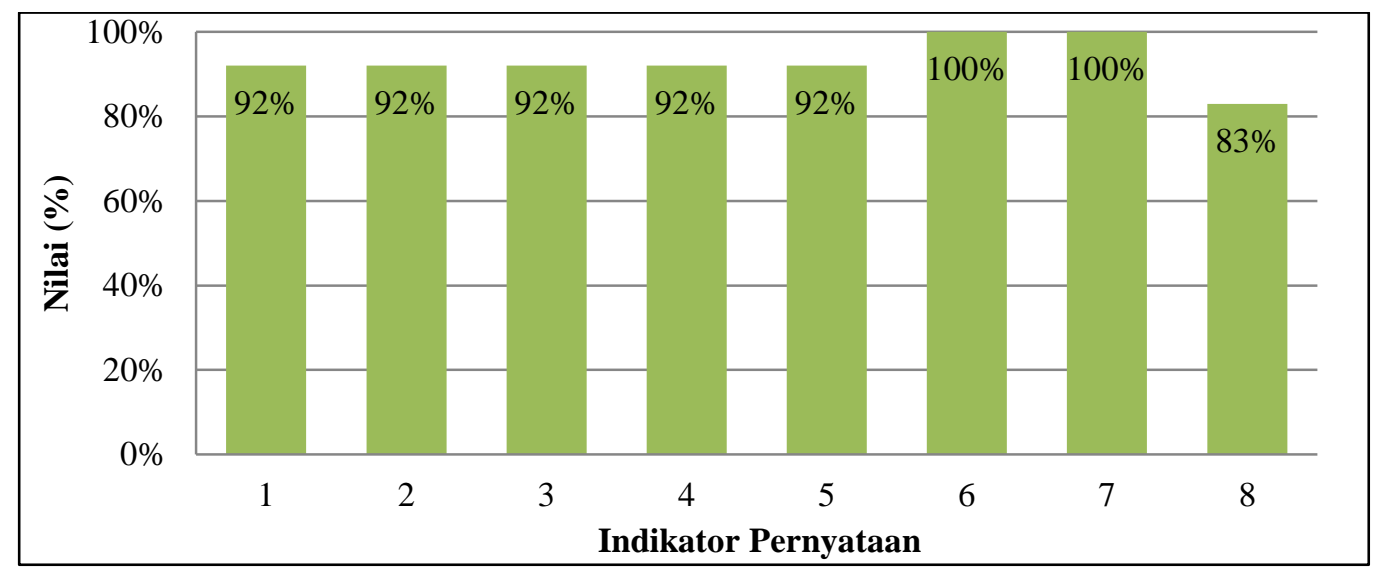

Gambar 3. Diagram Kelayakan Tampilan Produk Tiap Indikator Pernyataan

\section{Keterangan:}

1. Tata letak dan format pengetikan sesuai dengan kertas yang digunakan.

2. Sampul berwarna dan memuat gambar kultur masyarakat pesisir.

3. Tata letak teks dan gambar proporsional.

4. Jenis font (jenis huruf dan angka) bagus dan dapat dibaca.

5. Ukuran teks (ukuran huruf dan angka) proporsional.

6. Tanda-tanda untuk penekanan (cetak tebal/cetak miring).

7. Warna isi petunjuk praktikum menarik dan gambar memuat kultur masyarakat pesisir.

8. Tampilan secara keseluruhan mencerminkan kultur masyarakat pesisir.

Kelayakan tampilan produk dilihat pada rata-rata nilai yang diperoleh tiap indikator pernyataan (Gambar 3) hasilnya sangat bagus. Delapan indikator memperoleh persentase nilai diatas $80 \%$ yaitu dengan kriteria sangat layak. Persentase tertinggi yaitu pada indikator 
nomor 6 dan 7 yang memperoleh nilai sebesar $100 \%$.

\section{Revisi Pakar}

Petunjuk praktikum yang sebelumnya divalidasi oleh ahli dan dikatan layak telah melalui proses revisi. Revisi ini dilakukan setelah mendapatkan saran dari validator untuk diperbaiki.
Tujuan dilakukan revisi yaitu untuk memperbaiki kekurangan dari produk agar petunjuk praktikum IPA berbasis kultur masyarakat pesisir yang dihasilkan lebih baik lagi dari yang sebelumnya.Saransaran perbaikan dari validator telah diperbaiki sesuai keinginan tiap validator. Adapun desain produk sebelum dan setelah direvisi dapat dilihat pada Tabel 6 .

Tabel 6. Produk Sebelum dan Setelah Direvisi

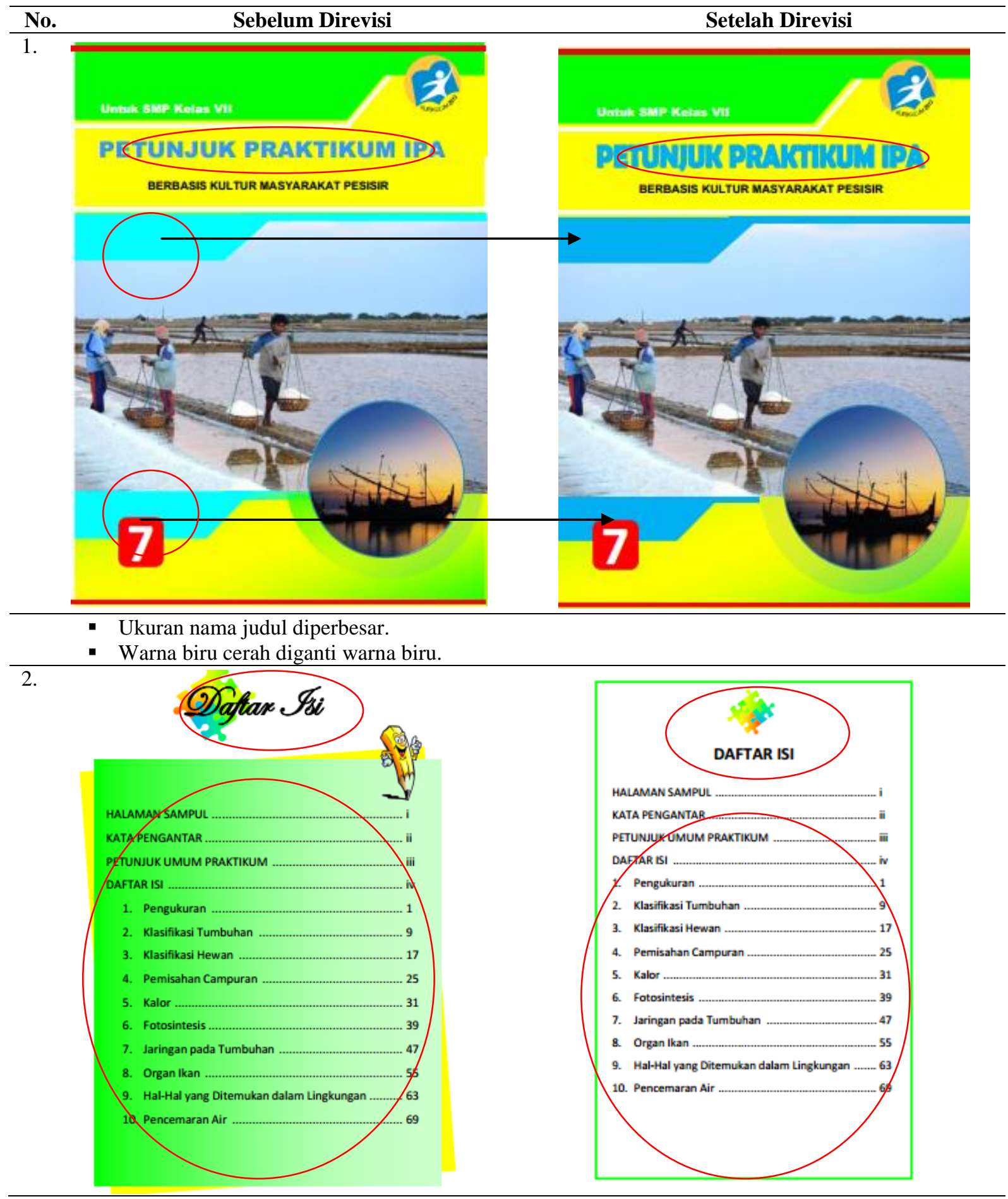




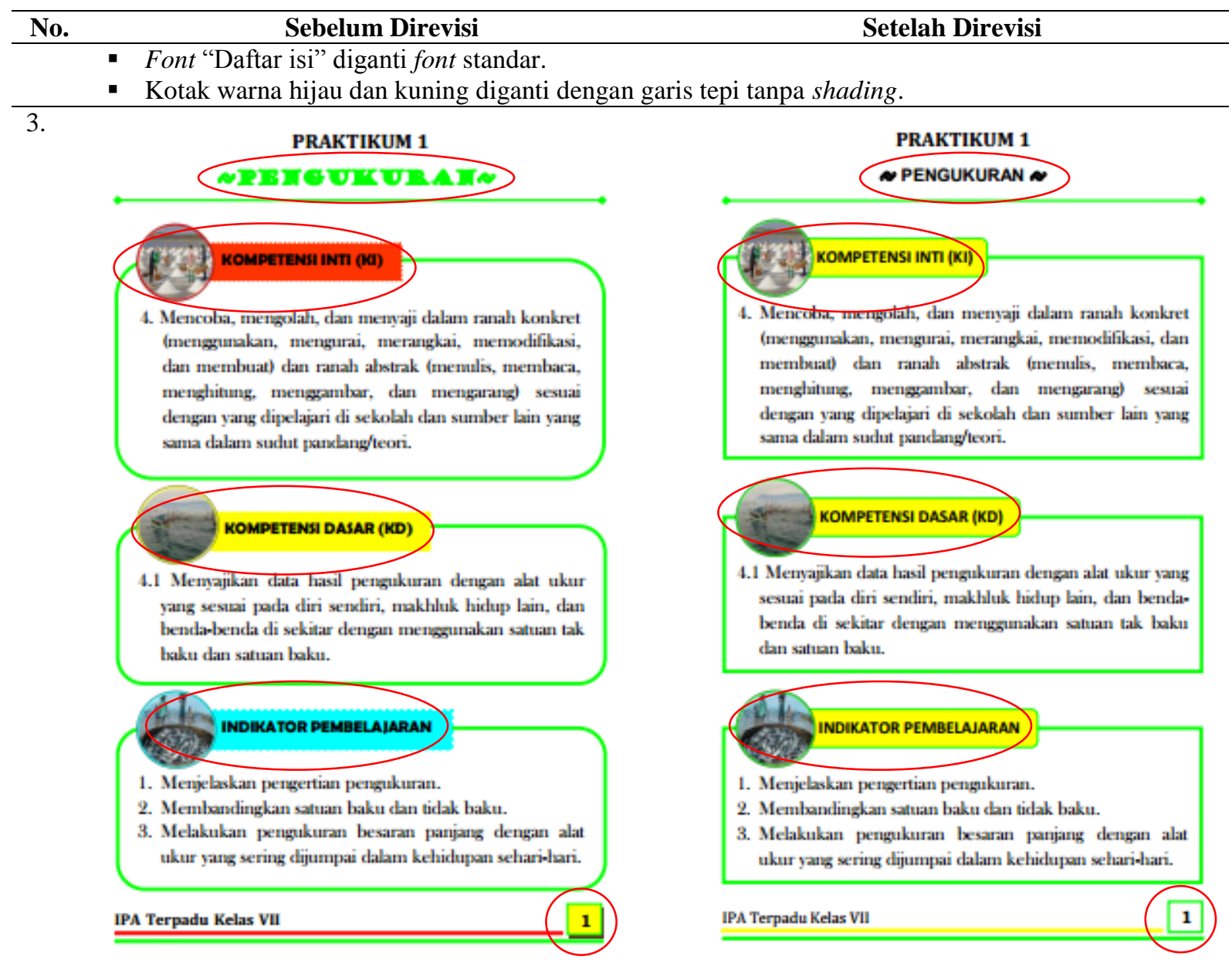

- Warna hijau pada judul diganti warna hitam.

- Simbol diantara kata pada judul harus diberik spasi.

- Warna pada desain tiap sub-judul disamakan.

- Kotak pada nomor halaman diganti dengan garis tepi saja tanpa shading.

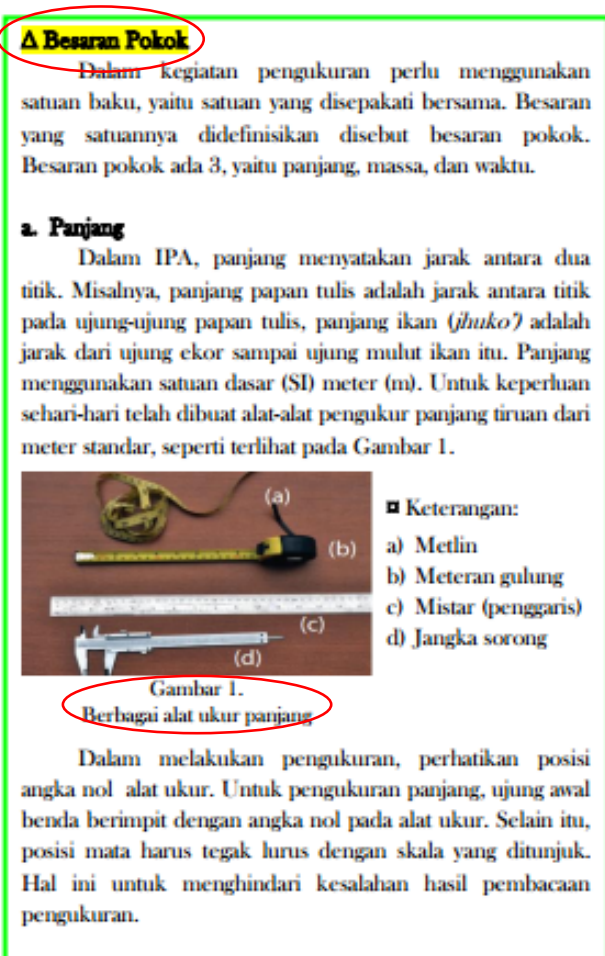

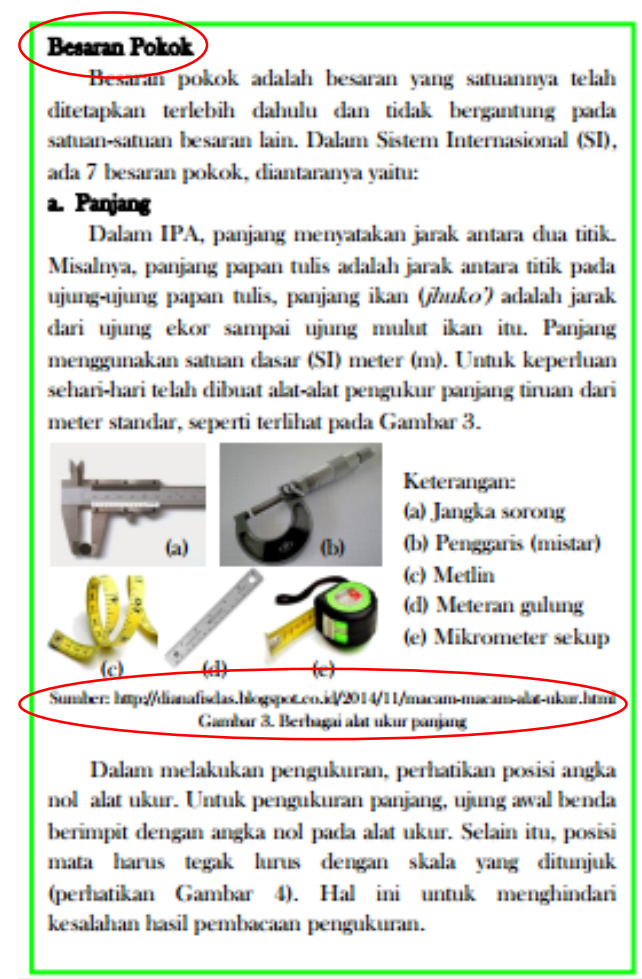




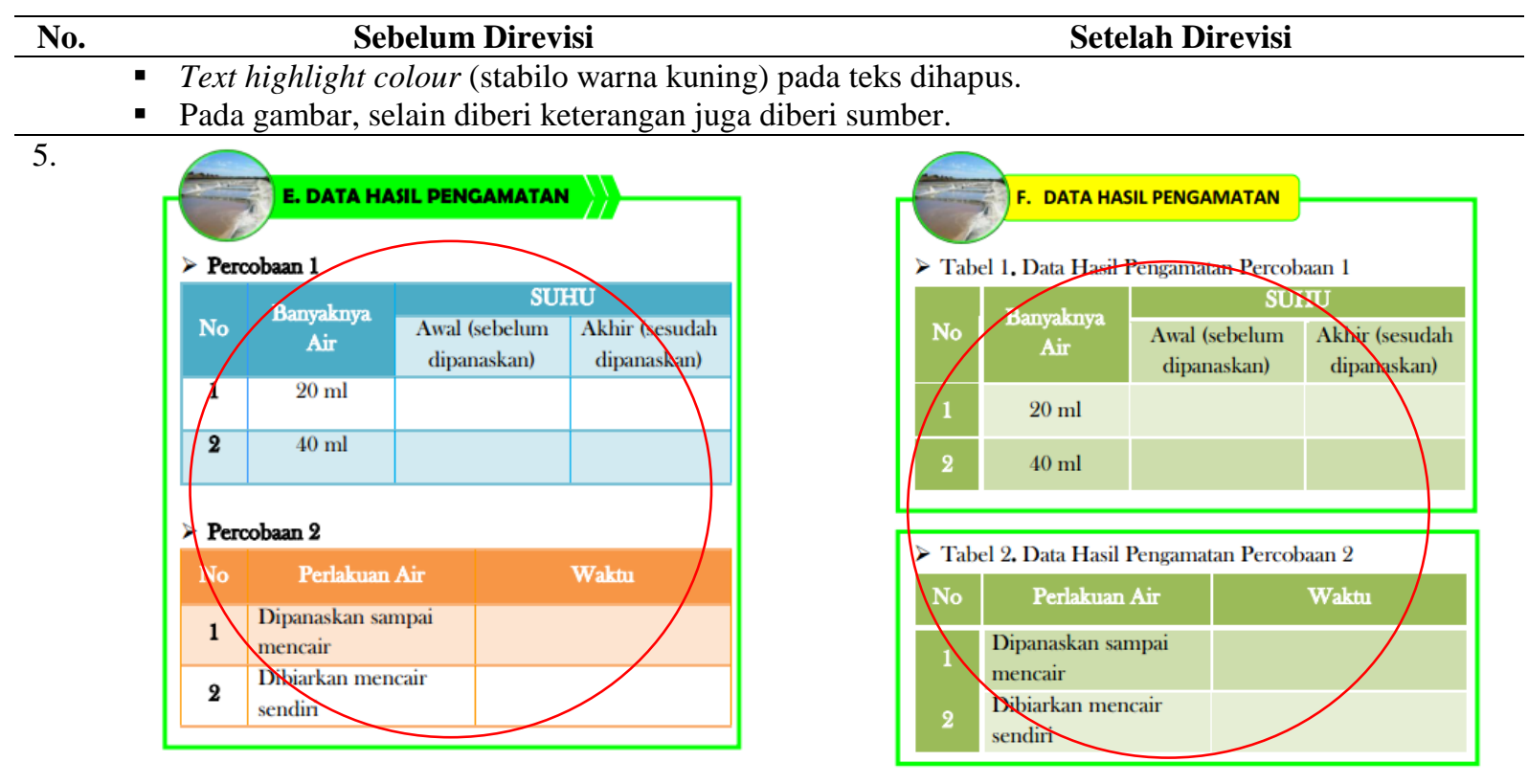

- Warna tabel pada tiap judul praktikum disamakan.

Sumber: Peneliti, diolah pada Juni 2017

\section{Uji Coba}

\section{a. Respon pada Tahap Simulasi Produk (one-to-one evulation)}

Pada tahap simulasi, produk yang telah direvisi diberikan kepada 3 siswa yang diambil secara acak di kelas VII untuk dimintai respon terhadap produk yang dikembangkan. Hasil dari respon siswa pada tahap simulasi produk dapat dilihat pada Gambar 4.

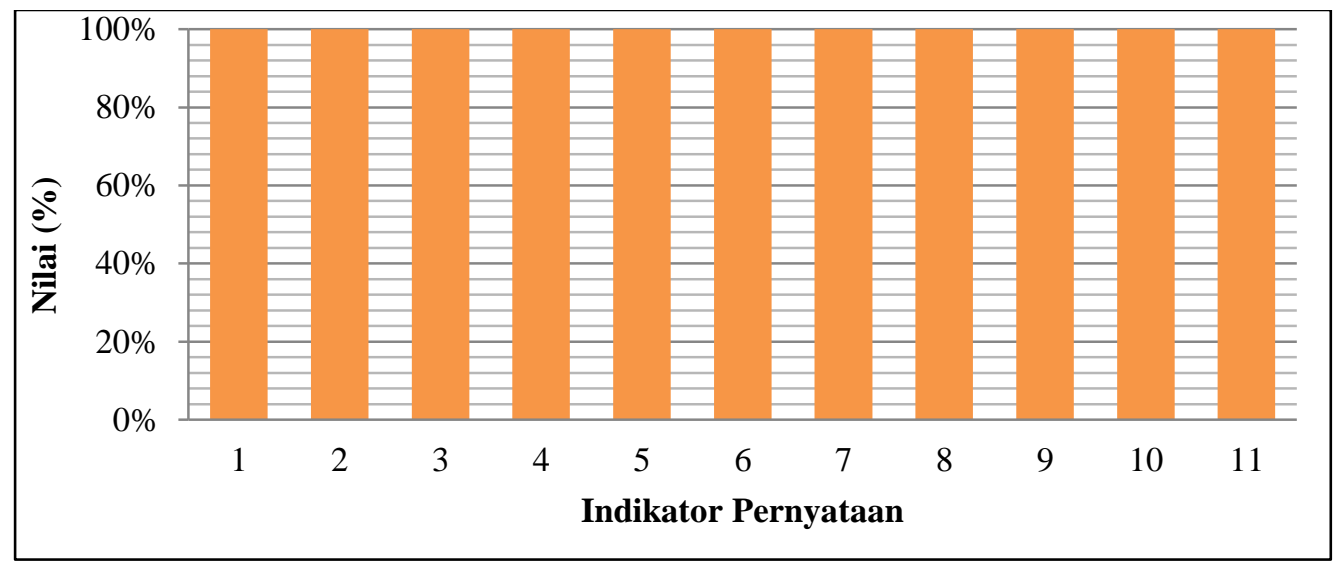

Gambar 4. Diagram Respon Siswa pada Tahap Simulasi Produk

\section{Keterangan:}

1. Tampilan menarik.

2. Jenis huruf dan angka bagus, jelas, dan dapat dibaca.

3. Gambar proporsional.

4. Nomor halaman teratur.

5. Pemilihan warna menarik dan cerah.

6. Penempatan antara gambar dan tulisan tepat.

7. Ukuran tulisan proporsional.

8. Terdapat gambar di lingkunggan sekitar.

9. Membantu melaksanakan kegiatan praktikum dengan mudah.

10. Langkah kerja jelas dan dimengerti tanpa penjelasan guru.

11. Membantu memahami materi yang diajarkan oleh guru. 
Gambar 4 menunjukkan respon siswa terhadap petuntuk praktikum IPA berbasis kultur masyarakat pesisir adalah positif, karena persentase nilai yang diperoleh pada tiap indikator pernyataan yaitu $100 \%$ dengan kriteria sangat baik.
Selain respon siswa, pada tahap simulasi produk ini juga meminta respon guru IPA kelas VII sebanyak 2 orang. Adapun hasil dari respon guru tersebut disajikan pada Gambar 5.

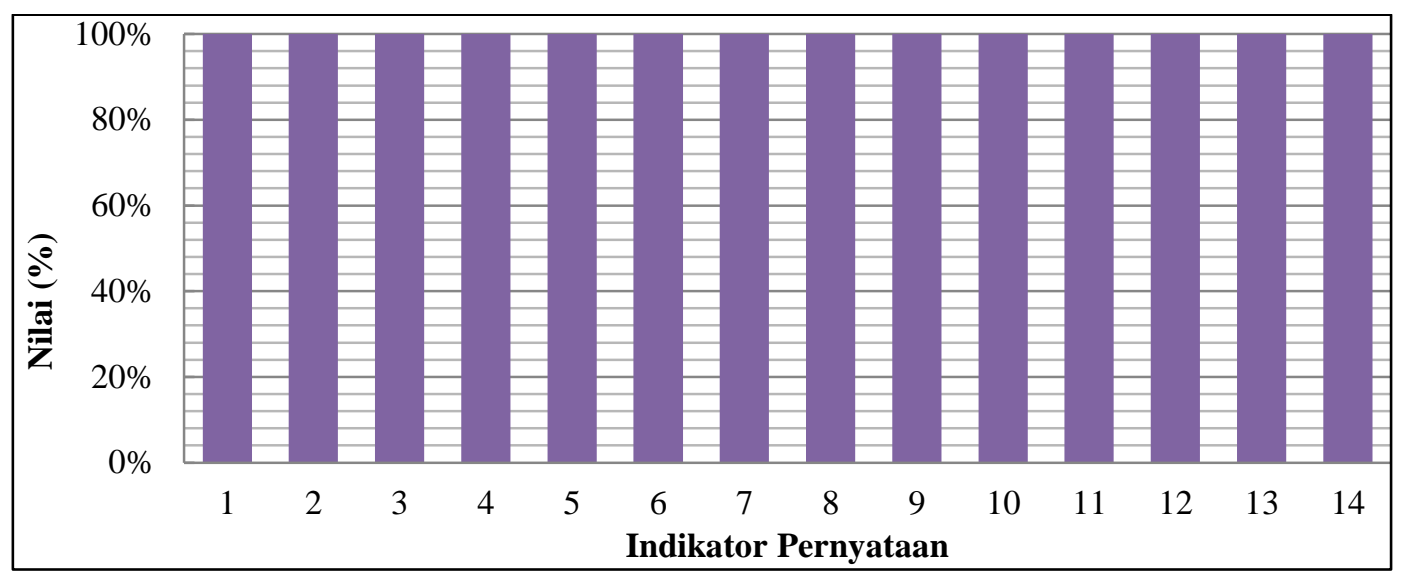

Gambar 5. Diagram Hasil Angket Respon Guru IPA

\section{Keterangan:}

1. Tampilan sampul menarik dan memuat gambar kultur masyarakat pesisir.

2. Font jelas dan dapat dibaca.

3. Gambar proporsional.

4. Penempatan antara gambar dan tulisan strategis.

5. Nomor halaman teratur dan bagus.

6. Pemilihan warna menarik dan cerah.

7. Ukuran teks proporsional.

8. Sesuai tahap perkembangan siswa.

9. Memuat kultur masyarakat pesisir.

10. Membantu siswa melaksanakan praktikum.

11. Membantu siswa memahami konsep yang dipelajari di kelas.

12. Langkah kerja dapat dimengerti siswa tanpa penjelasan guru.

13. Memudahkan guru melaksanakan kegiatan praktikum.

14. Tampilan produk mencerminkan kultur masyarakat pesisir.

Angket respon guru IPA yang disajikan pada Gambar 5 dapat diketahui bahwa hasilnya memuaskan, karena semua indikator pernyataan mendapatkan nilai $100 \%$ dengan kriteria sangat baik. Adapun komentar dari kedua guru IPA tersebut menyatakan bahwa petunjuk praktikum yang dikembangkan sudah bagus, isinya sudah baik sehingga memudahkan siswa untuk melakukan praktikum, dan deskripsi pertanyaan $90 \%$ sudah baik.

\section{b. Respon pada Tahap Uji Coba Pemakaian Produk (small group evaluation)}

Pada tahap uji coba kedua ini, diujikan kepada siswa sebanyak 9 orang yang dipilih secara acak dengan ketentuan bahwa siswa yang telah terpilih pada uji coba pertama tidak dipilih kembali. Sembilan orang siswa tersebut dimintai respon sama halnya dengan uji coba pertama menggunakan angket yang sama. Hasil respon siswa dapat dilihat pada Gambar 6. 


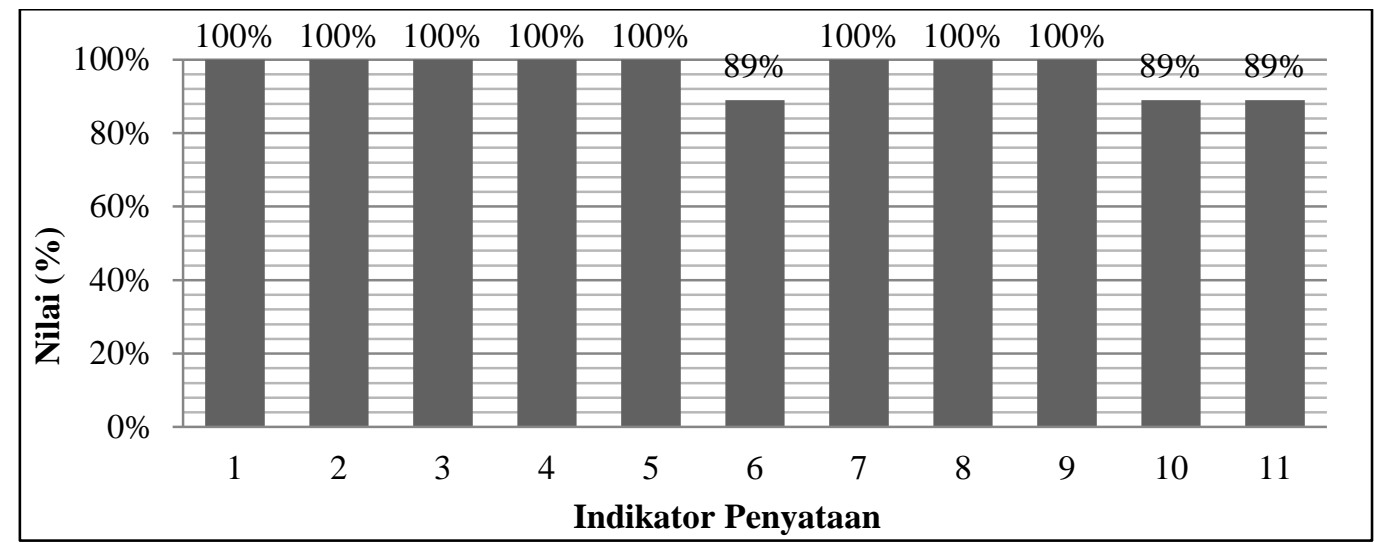

Gambar 6. Diagram Respon Siswa pada Tahap Uji Coba Pemakaian Produk

\section{Keterangan:}

1. Tampilan menarik.

2. Jenis huruf dan angka bagus, jelas, dan dapat dibaca.

3. Gambar proporsional.

4. Nomor halaman teratur.

5. Pemilihan warna menarik dan cerah.

6. Penempatan antara gambar dan tulisan tepat.

7. Ukuran tulisan proporsional.

8. Terdapat gambar di lingkunggan sekitar.

9. Membantu melaksanakan kegiatan praktikum dengan mudah.

10. Langkah kerja jelas dan dimengerti tanpa penjelasan guru.

11. Membantu memahami materi yang diajarkan oleh guru.

Pada Gambar 6. dapat diketahui bahwa respon siswa uji coba kedua ini hasilnya baik, meskipun tidak sempurna mendapatkan nilai $100 \%$ pada tiap indikator seperti pada uji coba pertama. Persentase terendah yaitu pada indikator pernyataan nomor 6 , 9, dan 10 yaitu sebesar $89 \%$. Hal ini dikarenakan penempatan gambar dan tulisan masih kurang tepat, petunjuk praktikum masih kurang membantu siswa dalam melaksanakan praktikum (hal ini didukung dengan banyaknya siswa yang masih bertanya terkait isi petunjuk praktikum), sehingga juga menyebabkan kurangnya siswa memahami materi yang diajarkan guru. Kriteria penilaiannya yaitu sangat baik, karena persentase 81\%-100\% termasuk dalam kriteria sangat baik (Parmin, 2013). Jika persentase respon siswa pada setiap indikator dirata-rata, maka hasilnya yaitu 96,9\% dengan kriteria sangat layak.

Respon siswa pada pada uji coba kedua ini diperoleh respon yang positif. Selain karena banyak yang memerikan jawaban "Iya", siswa juga memberikan komentar positif berupa pujian. Rata-rata siswa berkomentar petunjuk praktikum IPA berbasis kultur masyarakat pesisir ini sudah bagus karena dapat dimengerti oleh mereka.

Adapun untuk respon guru IPA pada tahap ini tidak dimintai lagi karena pada tahap uji coba pertama hasilnya sudah sangat memuaskan. Tahap selanjutnya yaitu revisi produk 2, yaitu melakukan perbaikan jika dari hasil uji coba kedua masih terdapat kekurangan. Akan tetapi, karena hasilnya bagus dan tidak terdapat saran untuk perbaikan, maka produk ini sudah dianggap bagus dan tidak perlu dilakukan revisi lagi.

\section{PEMBAHASAN}

\section{Kelayakan Petunjuk Praktikum IPA Berbasis Kultur Masyarakat Pesisir}

Petunjuk praktikum IPA yang dikembangkan sebelum diuji cobakan pada pengguna yaitu siswa dan guru IPA, dinilai kelayakannya telebih dahulu kepada para ahli. Kelayakan produk dilihat dari dua 
aspek, yaitu dari isi dan tampilan produk. Sebagaimana yang dikemukakan oleh Yannidah, Kurniawan and Aunillah (2013) bahwa "sebelum digunakan dalam kegiatan pembelajaran hendaknya perangkat pembelajaran telah mempunyai status valid. Dijelaskan bahwa idealnya pengembang perangkat pembelajaran perlu melakukan pemeriksaan ulang kepada para ahli (validator), khususnya mengenai: (a) ketepatan isi; (b) materi pembelajaran; (c) kesesuaian dengan tujuan pembelajaran; (d) desain fisik dan lain-lain. Dengan demikian, suatu perangkat pembelajaran dikatakan valid (baik/ layak), apabila telah dinilai baik oleh para ahli atau validator". Hal-hal tersebut sudah termuat dalam instumen yang digunakan untuk menilai kelayakan produk baik pada aspek isi dan tampilan produk. Dimana ketepatan isi, materi pembelajaran dan kesesuaian dengan tujuan pembelajaran termasuk dalam indikator penilaian untuk aspek isi produk, dan hal-hal yang menyangkut desain produk termasuk ke dalam aspek tampilan produk.

Indikator kelayakan produk yang dikembangkan dalam penelitian ini hanya dilihat dari penilaian oleh ahli isi dan tampilan produk. Hasil yang diperoleh untuk kelayakan pada aspek isi produk memperoleh pesentase sebesar $74 \%$ dengan kriteria layak. Adapun pada aspek tampilan poduk diperoleh nilai sebesar $92,7 \%$ dengan kriteria sangat layak. Berdasarkan nilai tersebut, dapat diketahui bahwa petunjuk paktikum IPA berbasis kultur masyarakat pesisir dikatakan layak dan dapat digunakan dalam pembelajaran.

Praktikum merupakan salah satu perwujudan kerja ilmiah dalam pembelajaran (Maharani, 2013). Pembelajaran dengan metode praktikum membutuhkan suatu petunjuk praktikum. Petunjuk praktikum tersebut bertujuan untuk menuntun siswa dalam melakukan praktikum dan membantu guru dalam mencapai tujuan pembelajaran". Begitupun dengan petunjuk praktikum IPA berbasis kultur masyarakat pesisir ini yang telah memperoleh kategori layak untuk digunakan dalam pembelajaran. Penyusunan petunjuk praktikum memiliki beberapa tujuan yaitu menyajikan bahan ajar yang memudahkan siswa untuk berinteraksi dengan materi yang diberikan; menyajikan tugas-tugas yang meningkatkan penguasaan siswa terhadap materi yang diberikan, melatih kemandirian belajar, memudahkan siswa dalam memberikan tugas kepada siswa (Prastowo, 2015).

Jika siswa dapat mengerti konsep IPA melalui kegiatan praktikum, maka tujuan pembelajaran dapat dicapai. Hal ini dikarenakan "praktikum memberi kesempatan kepada siswa untuk memenuhi dorongan rasa ingin tahu dan ingin bisa. Prinsip ini sangat menunjang kegiatan praktikum yang di dalamnya siswa menemukan pengetahuan melalui eksplorasinya terhadap alam (Rustaman, 2013). Sebagaimana yang dijelaskan oleh Arsyad (2013) bahwa "agar proses belajar mengajar dapat berhasil dengan baik, siswa sebaiknya diajak memanfaatkan semua alat inderanya. Guru berupaya untuk menampilkan rangsangan (stimulus) yang dapat diproses dengan berbagai indera. Semakin banyak alat indera yang digunakan untuk menerima dan mengolah informasi, semakin besar kemungkinan informasi terseebut dimengerti dan dapat dipertahankan dalam ingatan".

Manfaat petunjuk praktikum antara lain yaitu dapat mencapai ketuntasan belajar siswa dan menumbuhkan kebiasaan bekerja ilmiah (Meyhandoko, 2013). Salah satu indikator pernyataan yang dinilai dalam kelayakan produk pada aspek isi yaitu mempermudah kegiatan praktikum dan membantu siswa memahami konsep (Fotosinesis) memperoleh nilai sebesar $70 \%$ dengan kategori layak. Hal ini membuktikan bahwa dengan adanya petunjuk praktikum, kegiatan praktikum akan lebih mudah terlaksana sehingga siswa akan terbiasa dalam kegiatan kerja ilmiah dalam pembelajaran IPA. 
Jika siswa sudah terbiasa melakukan kerja ilmiah, maka akan mudah bagi siswa memahami materi pembelajaran, sehingga mudah pula bagi siswa mencapai ketuntasan belajar. Selayaknya yang dikemukakan oleh Yulaida (2016) bahwa "pembelajaran IPA merupakan pembelajaran yang berkaitan dengan cara mencari tahu, sehingga belajar IPA adalah suatu proses penemuan sebuah konsep yang dilakukan sendiri oleh siswa. Oleh karenanya siswa terlibat aktif dalam pembelajaran. Jika siswa tidak dibiasakan mencoba menemukan sendiri sebuah konsep yang dipelajari, maka pelajaran yang diterima tidak akan bermakna dan mudah terlupakan". Hal tersebut didukung oleh (Husamah et al., 2016) yang menyatakan bahwa "pembelajaran adalah proses atau usaha sadar dari pendidik untuk membantu siswa agar dapat belajar dengan baik sehingga terjadi perubahan tingkahlaku pada diri mereka, dimana perubahan itu dengan didapatkannya kemampuan baru yang berlaku dalam waktu yang relatif lama. Pembelajaran akan berjalan dengan baik jika komponen pembelajaran saling mendukung atau membangun, dalam hal ini pendidik sebagai fasilitator dan siswa sebagai subjek dalam pembelajaran".

\section{Respon Siswa dan Guru IPA}

Respon atau tanggapan diartikan sebagai hasil atau kesan yang didapat (ditinggal) dari pengamatan (Puspitasari, 2011). Adapun respon siswa dalam penelitian ini yaitu hasil penilaian siswa terhadap produk setelah mereka melakukan pengamatan, yaitu melihat tampilan produk dan membaca isi produk. Pengamatan tersebut akan meninggalkan kesan dalam diri siswa. Oleh karena itu, selain meminta penilaian dalam bentuk skala ordinal dengan 2 opsi jawaban yaitu "ya" dan "tidak". Siswa juga diminta memberikan komentar atau saran untuk mengetahui seperti apa kesan mereka terhadap petunjuk praktikum IPA berbasis kultur masyarakat pesisir.
Hasil penilaian siswa pada tahap simulasi produk memperoleh nilai $100 \%$ dengan kriteria sangat baik pada setiap indikator yang berjumlah 11 pernyataan. Hal ini dikarenakan Berdasarkan nilai tersebut dapat diketahui bahwa jawaban yang diberikan oleh siswa semuanya adalah jawaban positif yaitu "ya". Kusuma and Aisyah (2012) menyatakan bahwa "respon dapat muncul ketika adanya dukungan dan rintangan artinya dukungan menimbulkan perasaan senang dan rintangan menimbulkan perasaan tidak senang. Respon positif dapat meliputi jawaban ya, senang, menarik, jelas, serta perlu, sedangkan respon negatif meliputi jawaban tidak, tidak senang, tidak jelas, serta tidak perlu. Oleh karena itu, pada tahap ini respon siswa terhadap petunjuk praktikum IPA berbasis kultur masyarakat pesisir merupakan respon positif.

Berdasarkan hasil angket, respon siswa terhadap petunjuk praktikum IPA berbasis kultur masyarakat pesisir adalah sangat baik. Hal tersebut dapat dilihat dari masing-masing indikator pernyataan yang ada dalam angket yang diberikan kepada siswa. pernyataan no.1 (tampilan menarik), no.3 (gambar proporsional), dan no. 8 (terdapat gambar di lingkungan sekitar). Indikator-indikator tersebut sudah memenuhi syarat-syarat pemilihan gambar yaitu: (1) gambar harus bagus, jelas, menarik, mudah dimengerti dan cukup besar untuk dapat memperlihatkan detail; (2) apa yang tergambar harus cukup penting dan cocok untuk hal yang sedang dipelajari atau masalah yang sedang dihadapi; (3) gambar harus benar dan autentik, artinya menggambarkan situasi yang serupa jika dilihat dalam keadaan sebenarnya.

Respon positif siswa juga didapat dari indikator berikut yaitu pada no. 2 (jenis huruf dan angka bagus, jelas, dan dapat dibaca), no. 7 (ukuran tulisan proporsional), dan no. 10 (langkah kerja jelas dan dimengerti tanpa penjelasan guru). Hal tersebut sudah sesuai dengan yang dikemukakan Meyhandoko (2013) 
bahwa dalam pengembangan bahan ajar tertulis harus memperhatikan beberapa hal sebagai berikut:

1. Susunan tampilan, yang menyangkut urutan yang mudah, judul yang singkat, struktur kognitifnya jelas.

2. Bahasa yang mudah, menyangkut mengalirnya kosa kata, jelasnya kalimat, jelasnya hubungan kalimat, kalimat yang tidak terlalu panjang.

3. Menguji pemahaman, yang menyangkut menilai melalui orangnya, check list untuk pemahaman.

4. Stimulan, yang menyangkut enak tidaknya dilihat, tulisan mendorong pembaca untuk berpikir, menguji stimulan.

5. Kemudahan dibaca, yang menyangkut keramahan terhadap mata (huruf yang digunakan tidak terlalu kecil dan enak dibaca), urutan teks terstruktur, mudah dibaca.

6. Materi instruksional, yang menyangkut pemilihan teks, bahan kajian, lembar kerja (work sheet).

Pernyataan no. 9 (membantu melaksanakan kegiatan praktikum dengan mudah), dan no. 11 (membantu memahami materi yang diajarkan oleh guru), siswa memberikan jawaban ya pada indikator tersebut. Hal ini karena dalam produk yang dikembangkan dikaitkan dengan kultur dari daerah mereka sendiri, sehingga pengetahuan yang telah mereka peroleh sebelumnya dari pengalaman mereka mengenai lingkungan tempat mereka tinggal, tidak jauh berbeda dengan pengetahuan yang mereka dapatkan dari produk yang dikembangkan. Seperti yang dikemukakan oleh Jauhar (Widiadnyana, Sadia and Suastra, 2014), "bahwa interaksi dengan lingkungan dapat memperbaiki pemahaman dan memperkaya pengetahuan". Oleh karena itu, siswa merasa lebih mudah mengerti terhadap produk karena dikaitkan dengan kultur daerah mereka sendiri, dan memudahkan mereka juga untuk memahami materi yang diajarkan oleh guru. Sebagaimana yang dipaparkan oleh Saputra, Wahyuni and
Handayani (2016) bahwa bahan ajar yang mengorientasikan sains berbasis kearifan lokal daerah pesisir dapat meningkatkan pemahaman konsep siswa.

Respon siswa pada pada uji coba pemakaian produk ini adalah respon positif. Selain karena banyak yang memberikan jawaban iya, juga memberikan komentar yang positif sepeti "buku ini sangat bagus, dan banyak materi yang bisa kita ketahui”. Rata-rata siswa menyatakan bahwa petunjuk praktikum IPA berbasis kultur masyarakat pesisir ini bagus. Hal tersebut sejalan dengan fungsi dari petunjuk paktikum yang dikemukakan oleh Arifah, Maftukhin, \& Fatmaryanti (2014) bahwa "petunjuk praktikum dimaksudkan untuk memperlancar dan memberikan bantuan informasi atau materi pembelajaran sebagai pegangan bagi siswa dalam melakukan kegiatan praktikum". Seperti halnya petunjuk praktikum IPA berbasis kultur masyarakat pesisir ini yang dibuat dalam rangka untuk memudahkan siswa dalam melakukan praktikum dan membantu mereka memahami kegiatan praktikum yang akan dilakukan dengan memanafaatkan lingkungan disekitar mereka.

Tahap simulasi produk tidak hanya meminta respon siswa saja, tetapi juga meminta respon guru IPA terhadap produk yang telah dibuat, yaitu guru IPA pada kelas VII yang berjumlah dua orang. Hasil dari angket, diketahui bahwa hasilnya memuaskan, karena semua indikator pernyataan mendapatkan nilai $100 \%$ dengan kriteria sangat baik. Penilaian yang diberikan oleh guru tersebut sama halnya dengan penilaian yang diberikan oleh siswa terhadap produk, yaitu pada semua indikator pernyataan kedua guru IPA memberikan jawaban "ya". Hal ini berarti respon guru IPA merupakan respon yang positif.

Adapun komentar yang diberikan oleh guru IPA menyatakan bahwa petunjuk praktikum yang dikembangkan sudah bagus, isinya sudah baik sehingga memudahkan siswa untuk melakukan 
praktikum, dan deskripsi pertanyaan $90 \%$ sudah baik. Hal ini sesuai dengan pernyataan Arifah, Maftukhin, \& Fatmaryanti (2014) bahwa "salah satu fungsi dari buku petunjuk praktikum yaitu bahan ajar yang bisa meminimalkan peran guru". Hal ini dikarenakan, jika petunjuk paktikum yang dipakai oleh siswa mudah untuk digunakan tanpa harus bantuan penjelasan dari guru lagi, maka akan menghemat waktu siswa dan guru, sehingga peran guru yang awalnya masih menjadi peran utama dalam kegiatan praktikum akan tergantikan oleh siswa.

\section{KESIMPULAN}

Berdasarkan hasil penelitian yang telah dilakukan dapat disimpulakan bahwa:

1. Kelayakan petunjuk praktikum IPA berbasis kultur masyarakat pesisir yaitu sebesar $74 \%$ dengan kriteria layak untuk isi petunjuk praktikum. Sedangkan kelayakan tampilan produk yaitu $92,7 \%$ termasuk dalam kriteria sangat layak.

2. Respon siswa terhadap petunjuk praktikum IPA berbasis kultur masyarakat pesisir yaitu $100 \%$ pada tahap simulasi produk dan $96,9 \%$ pada uji coba pemakaian produk. Kedua nilai tersebut termasuk dalam kategori sangat baik. Respon guru IPA terhadap produk yang dikemangkan memperoleh nilai sebesar 100\% dengan kategori sangat baik.

\section{SARAN}

Saran yang dapat peneliti ajukan adalh sebagai berikut.

1. Bagi peneliti jika ingin memperoleh data yang lebih akurat mengenai permasalahan yang dialami siswa maka wawancara kepada siswa harus dilakukan pada semua kelas.

2. Jika ingin mengetahui kondisi nyata yang dialami siswa maka harus melakukan observasi langsung.

\section{DAFTAR PUSTAKA}

Arifah, I., Maftukhin, A. and Fatmaryanti, S. D. (2014) 'Pengembangan Buku Petunjuk Praktikum Berbasis Guided Inquiry untuk Mengoptimalkan Hands On Mahasiswa Semester II Program Studi Pendidikan Fisika Universitas Muhammadiyah Purworejo Tahun Akademik 2013 / 2014', Radiasi, 5(1), pp. 24-28.

Arsyad, A. (2013) Media Pembelajaran. Jakarta: PT. Raja Grafindo Persada.

Habibi, Anekawati, A. and Wati, H. D. (2012a) Hambatan Guru IPA SMP di Daerah Pesisir Sumenep untuk Mengembangkan Pembelajaran Kontekstual. Sumenep: FKIP Unija.

Habibi, Anekawati, A. and Wati, H. D. (2012b) Pembelajaran IPA Berbasis Kultur Masyarakat. Sumenep: FKIP Unija.

Husamah et al. (2016) Belajar dan Pembelajaran. Malang: UMM Press.

Kunandar (2014) Penilaian Autentik (Penilaian Hasil Belajar Peserta Didik Bedasarkan Kurikulum 2013). Jakarta: PT. Raja Grafindo Persada.

Kusuma, F. W. and Aisyah, M. N. (2012) 'Implementasi Model Pembelajaran Kooperatif Tipe Think Pair Share untuk Meningkatkan Aktivitas Belajar Akuntansi Siswa Kelas XI IPS 1 SMA Negeri 2 Wonosari tahun Ajaran 2011/2012', Jurnal Pendidikan Akuntansi Indonesia, $\mathrm{X}(2)$, pp. 43-63.

Maharani, M. U. (2013) Pengembangan Petunjuk Praktikum IPA Terpadu Tema Fotosintesis Berbasis Learning Cycle untuk Siswa SMP. Universitas Negeri Semarang.

Meyhandoko, A. (2013) Pengembangan Petunjuk Praktikum Kontekstual dengan Pemanfaatan Kondisi Lingkungan Lokal dalam Pembelajaran Materi Pencemaran di SMAN 2 Rembang. Universitas Negeri Semarang. 
Parmin (2013) Pengembangan Buku Petunjuk Praktikum IPA Terpadu Tema Mikroskop Berbasis Inkuiri Terbimbing Bermuatan Karakter. Universitas Negeri Semarang.

Permendikbud (2013) 'Peraturan Menteri Pendidikan dan Kebudayaan Nomor 68 Tahun 2013 tentang Kerangka Dasar dan Struktur Kurikulum Sekolah Menengah Pertama/Madrasah Tsanawiyah'. Jakarta: Kementrian Pendidikan dan Kebudayaan. Available at: http://direktori.madrasah.kemenag.go .id/media/files/Permendikbud68TH2 013.pdf.

Prastowo, A. (2015) Panduan Kreatif Membuat Bahan Ajar Inovatif. Jogjakarta: DIVA Press.

Puspitasari, A. R. (2011) Respon Siswa SMP Negeri 3 Kelapa Bangka Belitung terhadap Film Laskar Pelangi. Universitas Islam Negeri Syarif Hidayatullah.

Rustaman, N. (2013) Peranan Praktikum dalam Pembelajaran Biologi. Bandung. Available at: http://file.upi.edu/Direktori/SPS/PRO DI.PENDIDIKAN_IPA/1950123119 79032NURYANI_RUSTAMAN/PE RANAN_PRAKTIKUM_DALAM_ PEMBELAJARAN_BIOLOGI.pdf.

Saputra, A., Wahyuni, S. and Handayani, Ri. D. (2016) 'Pengembangan Modul IPA Berbasis Kearifan Lokal Daerah Pesisir Puger pada Pokok Bahasan Sistem Transportasi di SMP', Jurnal Pembelajaran Fisika, 5(2), pp. 182189.

Setiawan, H. W. and Wiyardi, R. S. (2015) 'Penggunaan App Inventor dalam Pembuatan Game Education Berbasis Android sebagai Media Pembelajaran yang Mandiri dan Interaktif untuk Meningkatkan Hasil Belajar Siswa TITL pada Pembelajaran Listrik Dasar SMK Muhammadiyah Majenang', Edu Elektrika Journal, 4(1), pp. 24-30.
Subamia, I. D. P., Wahyuni, I. G. A. N. S. and Widiasih, N. N. (2015) 'Pengembangan Perangkat Praktikum Berorientasi Lingkungan Penunjang Pembelajaran IPA SMP Sesuai Kurikulum 2013', Jurnal Pendidikan Indonesia, 4(2), pp. 675685.

Sugiyono (2016) Metode Penelitian dan Pengembangan (Research and Development/ $R \& D)$. Bandung: Alfabeta.

Waluyo, M. E. and Parmin (2014) 'Pengembangan Panduan Praktikum IPA Terpadu Berbasis Inkuiri Terbimbing Tema Fotosintesis untuk Menumbuhkan Keterampilan Kerja Ilmiah Siswa SMP', Unnes Science Education Journal, 3(3), pp. 677684.

Widiadnyana, Sadia and Suastra (2014) 'Pengaruh Model Discovery Learning Terhadap Pemahaman Konsep IPA dan Sikap Ilmiah Siswa SMP', e-Journal Program Pascasarjana Universitas Pendidikan Ganesha Program Studi IPA, 4(2), pp. 1-13.

Yannidah, N., Kurniawan, L. and Aunillah (2013) 'Pengembangan Perangkat Pembelajaran Matematika dengan Pendekatan Aptitude Treatment Interaction pada Efektivitas Pembelajaran Matematika', Jurnal Pendidikan Matematika STKIP PGRI Sidoarjo, 1(1), pp. 1-12.

Yulaida, D. (2016) Pengaruh Metode Praktikum terhadap Motivasi dan Hasil belajar IPA Siswa Kelas IV SDN Kemiri I Puspo Pasuruan. UNIVERSITAS ISLAM NEGERI MAULANA MALIK IBRAHIM MALANG. 